\title{
THIN-LAYER DRYING OF SHRIMP BY-PRODUCTS
}

\author{
Zabady, F. I. *
}

\begin{abstract}
Shrimp by-products from shrimp processing industry could be a good source for production of bioactive compounds as protein, lipid and minerals. The present study aimed to drying shrimp by-products (head and shell) which represent about $40-50 \%$ from total weight. The dry parameter was drying air temperature $\left(50,60,70\right.$ and $\left.80^{\circ} \mathrm{C}\right)$ and drying air velocity $(1,1.5$ and $2 \mathrm{~m} / \mathrm{s})$ at thickness layer of $8 \mathrm{~mm}$. The results indicated that the initial moisture content of $180 \%$ (d.b) decreased to a range between 10 and $8 \%$ (d.b) at the end of drying process depending on the drying conditions. For instance, the shortest drying time was at $150 \mathrm{~min}, 80^{\circ} \mathrm{C}$ drying air temperature and $2 \mathrm{~m} / \mathrm{s}$ air velocity. While, the longest drying time was recorded at 360 min with $50^{\circ} \mathrm{C}$ and $1 \mathrm{~m} / \mathrm{s}$ air velocity.
\end{abstract}

\section{INTRODUCTION}

hrimp (penaeusvannamei) by-products is a high source of protein $(50 \%)$ and it undergoes rapid disintegration which leading to environmental pollution. It is necessary to preserve the material adopting the environmentally safe techniques. Shrimp processing for freezing normally involves removal of head and body carapace. Processing of shrimps produced large quantities of solid wastes. The solid shrimp waste contains head and body shell represents approximately $40-50 \%$ of whole shrimp weight. The tropical shrimps, the head generally constitutes of $34-45 \%$ and body shell constitutes of 10 15\% (Barratt and Montano1986). It was found that the shrimp byproducts can be used as a raw material for extraction of chitosan and lipid-mineral-rich carotenoprotein by combining chemical and biological treatment.

" Assoc. Prof. of Agric. Eng.; Fac. of Agric. Eng. Al-Azhar University, Cairo, Egypt. 
Chitosan has been recognized as a multifunctional bioactive compound and has been used widely in food, biotechnology, cosmetics and medicine. Lipid-mineral-rich carotenoprotein can be used as a supplement in food and aqua-feed with good nutrional and functional properties.

The results proved that high quality chitosan and lipid-mineral-rich carotenoprotein can be obtained from shrimp by-products (Trang and Phuong, 2012). Shrimp by-products with high economic value is considered as containing a high proportion of protein. As a result of neglect, lack of recycling is not take advantage of them and cause pollution of the environment with a high degree where it is fast decomposition produces odors and gases are corrupt. In some cases, shrimp by-products up to $50 \%$ of the shrimp mass. So now the world tended to recycle the by-products for use in different areas (diet poultry and shrimp diet). Total Egyptian shrimp production was about $21.8 \mathrm{Gg}$ $35-45 \%$ of this amount is by-product (GAFRD, 2014). Sobukola and Olatunde (2011) mentioned that drying of shrimp is important, because it preserves shrimp by inactivating enzymes and removing the moisture necessary for bacterial and mould growth. The safe moisture content for shrimp meal storage was lower than $12 \% \mathrm{db}$. It is important, for digestibility of shrimp meal, to maintain moisture around the protein. To accomplish this, it is essential to keep the maximum product temperature inside the dryers below $100^{\circ} \mathrm{C}$. If protein is over heated the amino acid structure will change. As a result, the protein is not easily recognized nor absorbed by the intestines of the animals. From a practical point of view, overheating of the fish meal makes the fish meal less digestible. Zhiqiang et al. (2013) reported that the hot convective drying of fresh tilapia fillets was evaluated in a heat pump dryer. The influence of the drying temperature $\left(35,45\right.$ and $\left.55^{\circ} \mathrm{C}\right)$, hot air velocity $(1.50,2.50$ and $3.50 \mathrm{~m} / \mathrm{s}$ ) and thickness $(3,5$ and $7 \mathrm{~mm})$ of the tilapia fillets on the moisture ratio and drying rate have been studied. It shows that drying process took place in falling rate periods. The experimental drying data 
of fresh tilapia fillets under different conditions was fitted to nine different commonly used thin-layer drying models. Constant drying rate period was not observed; the drying process took place in the falling-rate period. With the increase of the drying temperature, drying velocity and reduction of the thickness, the moisture ratio decreased and the drying rate increased.

The main objectives of this study were:

-Thin-layer drying characteristics of shrimp by-products using the thermal dryer at different air temperature and hot air velocity.

- Estimate drying cost of the dried shrimp by-products.

-Chemical analysis shrimp by-products.

\section{MATERIALS AND METHODS}

1. Shrimp by-products: Raw material by-products were obtained from Alobor market in the province of Cairo, Egypt. The by-products transfer immediately in plastic boxes containing crushed ice to the lab and packed in polyethylene bags and stored at $-18^{\circ} \mathrm{C}$ until the time of the experiment. Before any experimental range, by-products taken from the refrigerator and placed in the laboratory to achieve the ambient air temperature.

\section{Unit drying:}

This unit was developed, constructed by Galal (2015), of the Faculty Agricultural Engineering, Al-Azhar University, Nasr City, Cairo, Egypt. The dryer was fitted with a temperature control system. The dryer consists of. (Fig. (1)).

1. Forced air section: A small air blower of $300 \mathrm{~W}, 220 \mathrm{~V}$, made in China was used to supply the hot air flow rate. This blower connected to the air heating section.

2. Air control gate: Section of the steel sheet thickness of $10 \mathrm{~mm}$ moving up and down through the spiral nail to pass the amount of air required. 


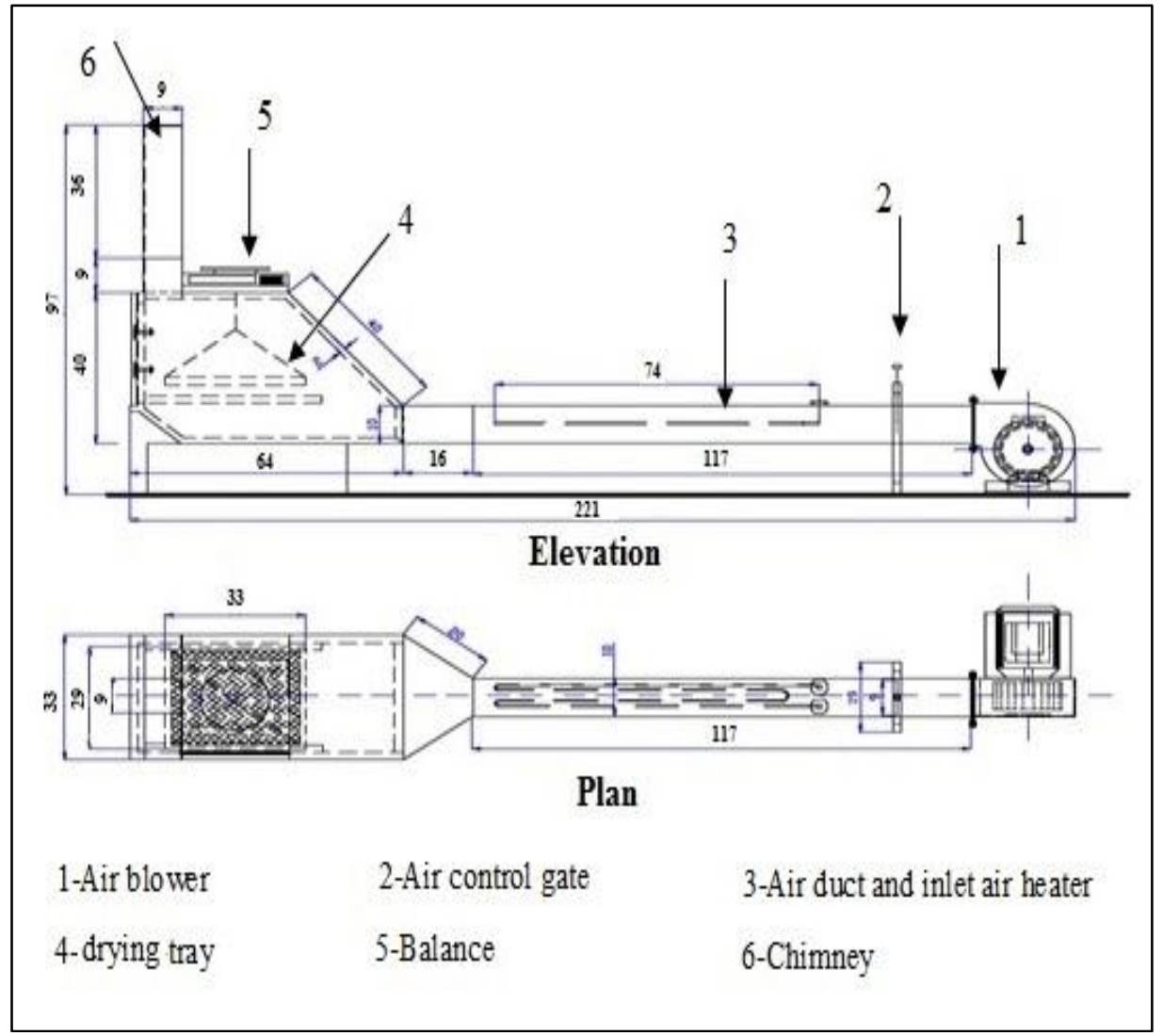

Fig. (1): Elevation and plan of unit drying.

3. Tray drying: Made of a fixed aperture wire mesh of galvanized steel for entering hot air to product parts, dimensions of $330 \times 270 \mathrm{~mm}$ framed of wood thickness of $30 \mathrm{~mm}$ rectangular shape.

4. Air heating section: Room with dimensions of $1300 \mathrm{~mm}$ length, $100 \mathrm{~mm}$ width, $100 \mathrm{~mm}$ high made of galvanized steel sheet of $0.5 \mathrm{~mm}$ thickness and insulated from the outside by glass wool with thickness of $30 \mathrm{~mm}$ to prevent heat loss. The electrical heater of $3 \mathrm{~kW}$ ( $\mathrm{U}$ form) was fixed inside the housing to heat the drying air.

5. Drying section: The drying chamber was constructed of wooden panels 400x330x300 mm (20mm thick), the side walls and bottom of drying chamber were insulated by foam layer. Drying air inters the chamber after leaving air heating section through an air duct from the bottom to 
the top of the dryer bin. The dryer door was made of wooden panels with dimensions of $330 \mathrm{~mm}$ long and $300 \mathrm{~mm}$ wide, the door was connecting to drying chamber by two hinges and tightly sealed by a rubber gasket during the drying process. Drying was mounted on a wooden stand of $800 \mathrm{~mm}$ height from the ground.

\section{Measurement instruments:}

1. Digital veneer caliper: To measure dimensions (Accuracy of $0.01 \mathrm{~mm}$ ).

2. Electric oven: with the following specifications (VENTICELL55 type, $230 \mathrm{~V}, 50 / 60 \mathrm{~Hz}, 1250 \mathrm{w}, 250 \mathrm{Max}$.tempruture) is used to determine the moisture content of by- products samples, at $105^{\circ} \mathrm{C}$ for 24 hour drying time.

3. Anemometer: To measured air velocity inside the drying chamber (Range from 0 to $44 \mathrm{~m} / \mathrm{s}$, accuracy of $0.1 \mathrm{~m} / \mathrm{s}$ ).

4. A digital balance was used for measuring the weight of the sample of by-products during drying ( $5 \mathrm{~kg}$ with sensitivity of $0.1 \mathrm{~g}$ ).

5. Temperature control device: Is connected to the temperature sensor inside the drying chamber for temperature sensor drying air temperature. This sensor is connected to a digital thermostat. Digital thermometers (a type of Dixell, not a model "XR10CX - 5N0C0" with accuracy of $0.1^{\circ} \mathrm{C}$. The sensitivity ranged from 0.1 to $2^{\circ} \mathrm{Cand}$ work in a temperature range of $0-400^{\circ} \mathrm{C}$.

\section{Initial moisture content of samples:}

Initial moisture content of samples was determined by oven at temperature of $105{ }^{\circ} \mathrm{C}$ for 24 hours (AOAC Standards, 2005). It can be calculated as follows:

$$
M_{i d}=\frac{W_{m}}{W_{d}} \times 100
$$

\section{Where:}

$\boldsymbol{M}_{\boldsymbol{i d}}=$ Moisture content dry basis (\%).

$\boldsymbol{W}_{\boldsymbol{m}}=$ Mass of water in sample $(\mathrm{g})$.

$\boldsymbol{W}_{\boldsymbol{d}}=$ Mass of dry material $(\mathrm{g})$. 
PROCESS ENGINEERING

2. Moisture content at any time $\left(m_{t}\right)$, (wet basis \%):

The moisture content, wet basis $\%$ is determined every 30 minutes as follows:

$$
\begin{array}{r}
\grave{A}=A\left(1-m_{i w}\right) \\
m_{t}=\frac{B-\grave{A}}{B}
\end{array}
$$

Where:

$\boldsymbol{A}^{\prime}=$ Mass of dry sample $(\mathrm{g})$.

$\boldsymbol{A}=$ Mass of fresh sample (g).

$\boldsymbol{B}=$ Mass of sample at any time $(\mathrm{g})$.

$\boldsymbol{m}_{\boldsymbol{i w}}=$ Initial moisture content, w b (\%). (Tayel et al., 2012).

3. Moisture content $\left(\mathbf{M}_{\mathrm{t}}\right)$, (dry basis \%):

The moisture content, dry basis $\%$ is determined every 30 minutes as follows (Tayel, et al., 2012):

$$
M_{t}=\frac{B-\grave{A}}{\grave{A}} \ldots \ldots \ldots \ldots \ldots \ldots \ldots \ldots
$$

4. Moisture ratio $(\mathrm{MR})(\mathrm{db} \%)$ and drying rate constant, $(\mathrm{k})$ : The Drying rate constant $(\mathrm{k})$ is determined as follows(Lewis, 1921):

$$
M R=\frac{M_{t}-M_{e}}{M_{i}-M_{e}}=e^{-K t}
$$

\section{Where:}

$\mathbf{M}_{\mathbf{i}}$ : Initial moisture content, \% (db).

$\mathbf{M}_{\mathbf{t}}$ : Moisture content at any time during drying, $\%(\mathrm{db})$.

$\mathbf{M}_{\mathbf{e}}$ : Equilibrium moisture content, \% (db).

k: Drying rate constant, $\min ^{-1}$.

t: Drying time, min.

Determination of the drying rate constant, (k): By using equation (5), "k" was expressed in a linear form as follows: 
So, plotting $\boldsymbol{l n} \boldsymbol{M} \boldsymbol{R}$ vs. $\mathbf{t}$ results in a slopping down straight line whose slope is $\mathbf{k}$.

5. Cost analysis: The dryer hourly costs were calculated based on the fixed costs and variable costs of convection dryer by using the following formula (Awady et al., 2003)

$$
C=\frac{P}{h}\left(\frac{1}{a}+\frac{i}{2}+t+r\right)+(W . e)+\frac{m}{200}
$$

Where: $\mathbf{C}=$ Dryer hourly cost, L.E. $/ \mathrm{h}, \boldsymbol{P}=$ Price of dryer, L.E., $=500$ L.E, $\mathbf{h}=$ Yearly working hours, which were is assumed in the present work to be:(300 day/year x 2 period/day x $8 \mathrm{~h} /$ period $=4800 \mathrm{~h} /$ year $), \boldsymbol{a}=$ Life expectancy of machine, about (10 Year), $\boldsymbol{i}=$ Interest rate/Year. (The bank interest in Egypt), which was about $11 \%, t=$ Taxes and overheads ratio, which is assumed in the present work to be $20 \%, r=$ Repair and maintenance ratio, which is assumed in the present work $10 \%$., $\boldsymbol{W}=$ Power of dryer $(\mathrm{kW}), \boldsymbol{e}=$ Hourly cost $/ \mathrm{kW} . \mathrm{h},(0.85$ L.E. $/ \mathrm{kW} . \mathrm{h}), \mathbf{m}=$ The monthly average wage, L.E., (1000 L.E), impose that here are 10 dryers becomes (100 L.E./man. dryer, month), $\mathbf{2 0 0}=$ The monthly average working hours.

$$
\operatorname{Cost}\left(\boldsymbol{L} . E / K g_{\text {dried product }}\right)=\frac{\text { Dryer hourly } \operatorname{cost}(\boldsymbol{L} . \mathrm{E} / \mathrm{h})}{\text { Dryer productivity }\left(\boldsymbol{k g} g_{\text {dried product }} / \boldsymbol{h}\right)}
$$

\section{RESULTS AND DISCUSSION}

\section{Behavior of the convection drying regimes:}

\subsection{Evaluation of the effect convection air temperatures, thickness of the layer, and velocity on the product moisture content and elapsed time:}

A single layer of shrimp by-products was dried in Thermal dryer under controlled condition of temperature, thickness of layer and air velocity. The drying experiments were conducted for temperature range of (50, 
$60,70$ and 80$){ }^{\circ} \mathrm{C}$, thickness of layer $8 \mathrm{~mm}$ and air velocity range of $(1$, 1.5 and $2 \mathrm{~m} / \mathrm{s}$ ). General trend was observed where, the moisture content decreased with the increasing in drying air temperature, air velocity and drying time. The limited information is available on the kinetics of water removal from shrimp by-products. The decreased moisture content could be attributed to increased evaporation of water both on the surface and in the by-products due to increasing temperatures and velocities of drying air. Fig. (2) shows that the moisture content of $180 \%$ (db) decreased to rang between 10 and $8 \%(\mathrm{db})$ at the end drying process depending on the drying conditions. For instance, the shortest drying time was recorded at $150 \mathrm{~min}$ with $80^{\circ} \mathrm{C}$ drying air temperature and $2 \mathrm{~m} / \mathrm{s}$ air velocity. While, the longest drying time was recorded at $360 \mathrm{~min}$ with $50^{\circ} \mathrm{C}$ and $1 \mathrm{~m} / \mathrm{s}$ air velocity. One drying model (Lewis's) has been used to describe drying curve. The model type, model constant and determination coefficient $\left(\mathrm{R}^{2}\right)$ of one different models used for moisture ratio change with drying time are presented in Table (1). Based on these results, the mode drying curves in all the treatments tested.

\subsection{Drying constant $(K)$ :}

Table (1) shows the drying constant values (k) obtained at different temperatures and air velocities of shrimp by-products. The correlation coefficient $\left(\mathrm{R}^{2}\right)$ ranging between 0.8609 and 0.9753 , it is noted that the $\mathrm{k}$ values have been steadily increasing with the increase in both temperatures and air velocities. Figs (3) reveal the relation between (K) and $(\mathrm{T})$ at different $(\mathrm{V})$ the figure shows that the relation between $(\mathrm{T})$ and (K) was exponential relation as:

$$
K=a T^{b}
$$

Table (2) and Fig (4) show the relation between parameter a, b and V it's clear that the relation was linear equation as:

$$
b=-0.7746 V+2.6327
$$

From equation (9) and (10) the relation was as following:

$$
K=7.53 E-05 T^{-0.7746 V+2.6327} R^{2}=0.9452
$$




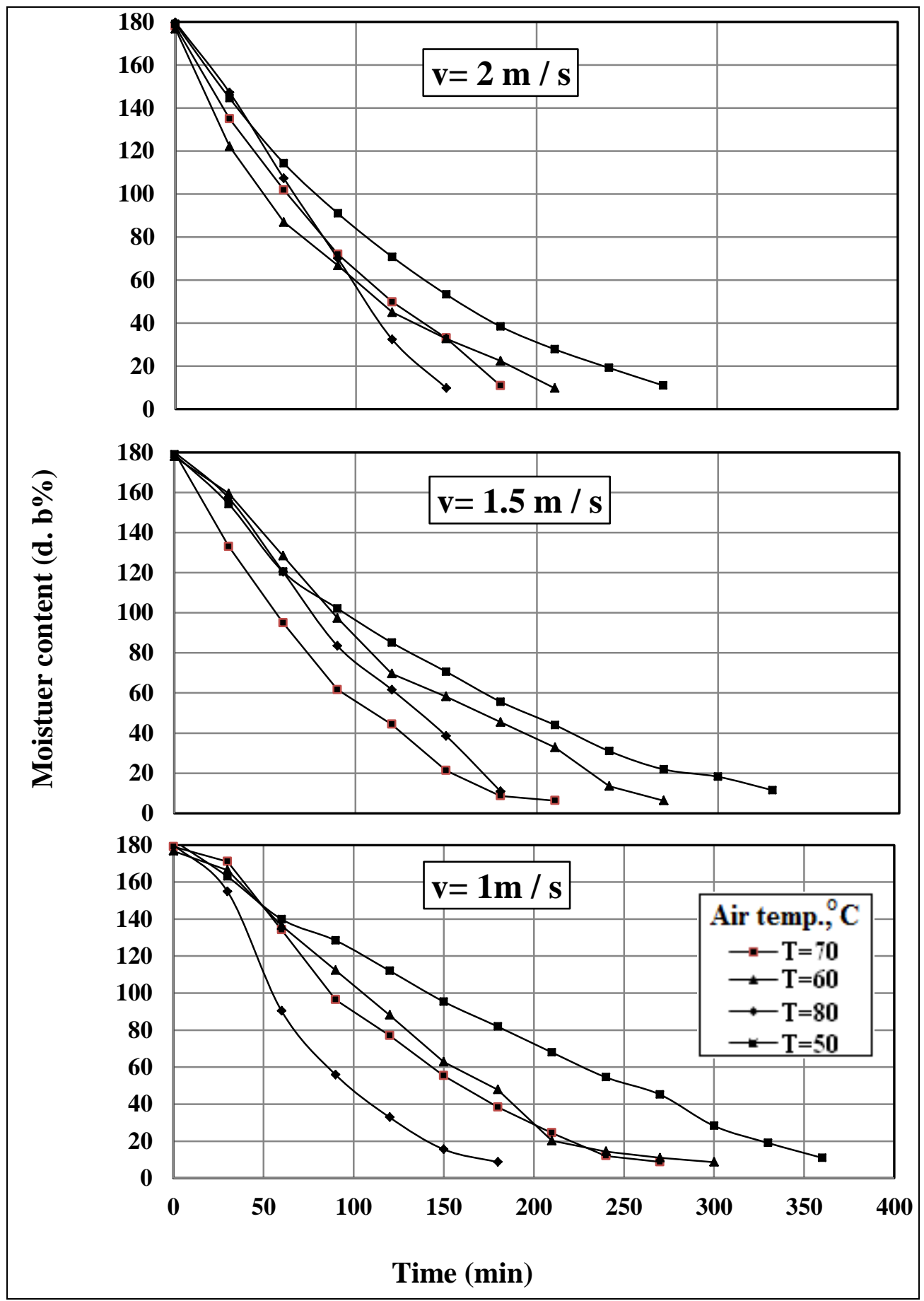

Fig. (2): Moisture content (db \%) as related to drying time (min) at different velocities $(\mathrm{m} / \mathrm{s})$ and drying air temperature $\left({ }^{\circ} \mathrm{C}\right)$. 
Table (1): Drying rate constants.

\begin{tabular}{|c|c|c|}
\hline Velocity $\mathbf{m} / \mathbf{s}$ & $\begin{array}{c}\text { Temperature } \\
\text { C }\end{array}$ & $\begin{array}{c}K\left(\min ^{-1}\right) \text { Drying } \\
\text { constant }\end{array}$ \\
\hline \multirow{4}{*}{2} & 80 & 0.0183 \\
\hline & 70 & 0.0149 \\
\hline & 60 & 0.0144 \\
\hline & 50 & 0.0107 \\
\hline \multirow{4}{*}{1.5} & 80 & 0.022 \\
\hline & 70 & 0.0189 \\
\hline & 60 & 0.0147 \\
\hline & 50 & 0.0106 \\
\hline \multirow{4}{*}{1} & 80 & 0.0183 \\
\hline & 70 & 0.0116 \\
\hline & 60 & 0.0112 \\
\hline & 50 & 0.0071 \\
\hline
\end{tabular}

Table (2): Parameters (a) and (b) at different air velocity (v).

\begin{tabular}{|c||c||c|}
\hline $\mathbf{v}(\mathbf{m} / \mathbf{s})$ & $\mathbf{a}$ & $\mathbf{b}$ \\
\hline \hline 2 & $2.00 \mathrm{E}-04$ & 1.0564 \\
\hline 1.5 & $2.00 \mathrm{E}-05$ & 1.5249 \\
\hline 1 & $6.00 \mathrm{E}-06$ & 1.831 \\
\hline
\end{tabular}




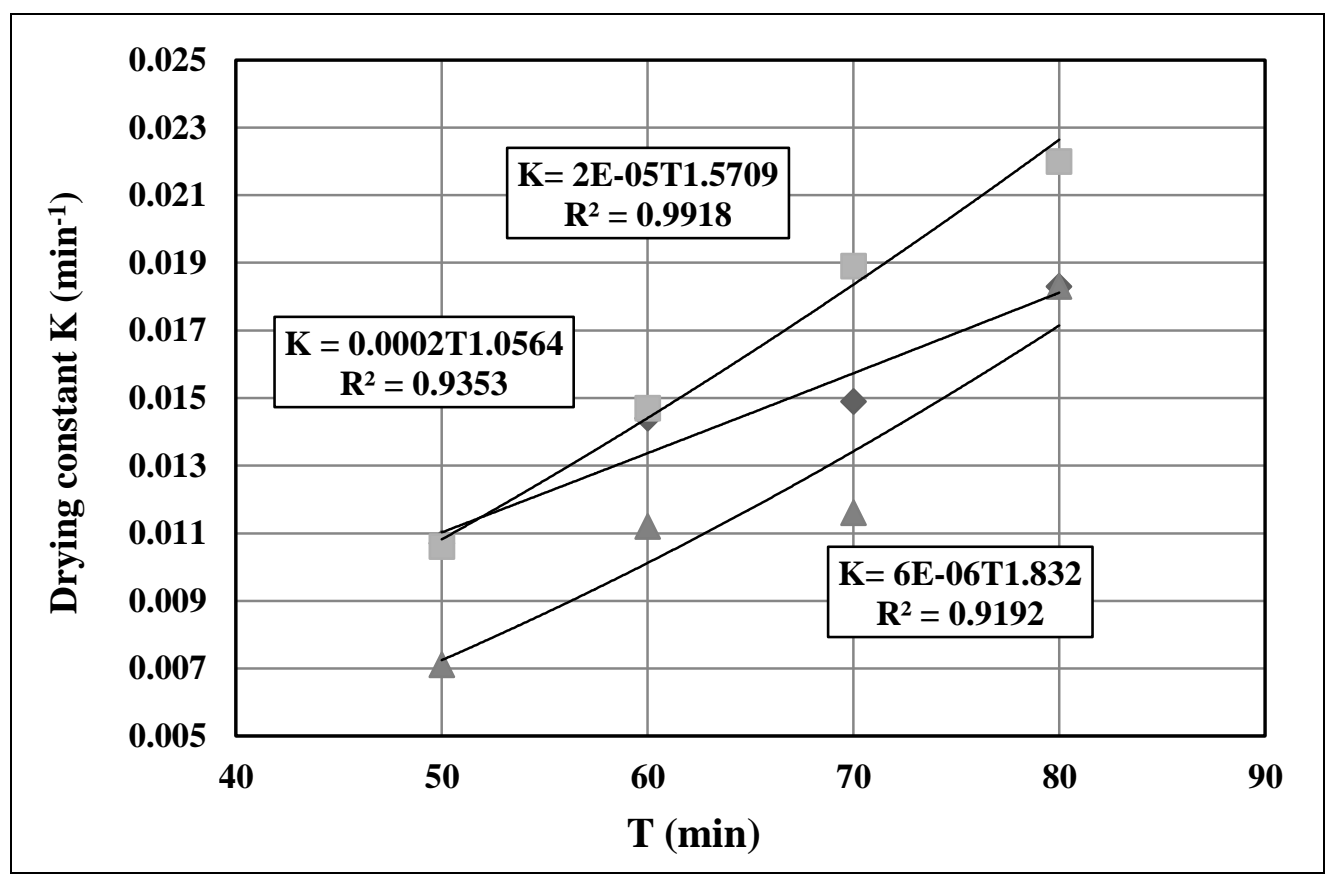

Fig. (3): The relation between drying time ( $T$ ) and drying constant (K) at different air velocity (v).

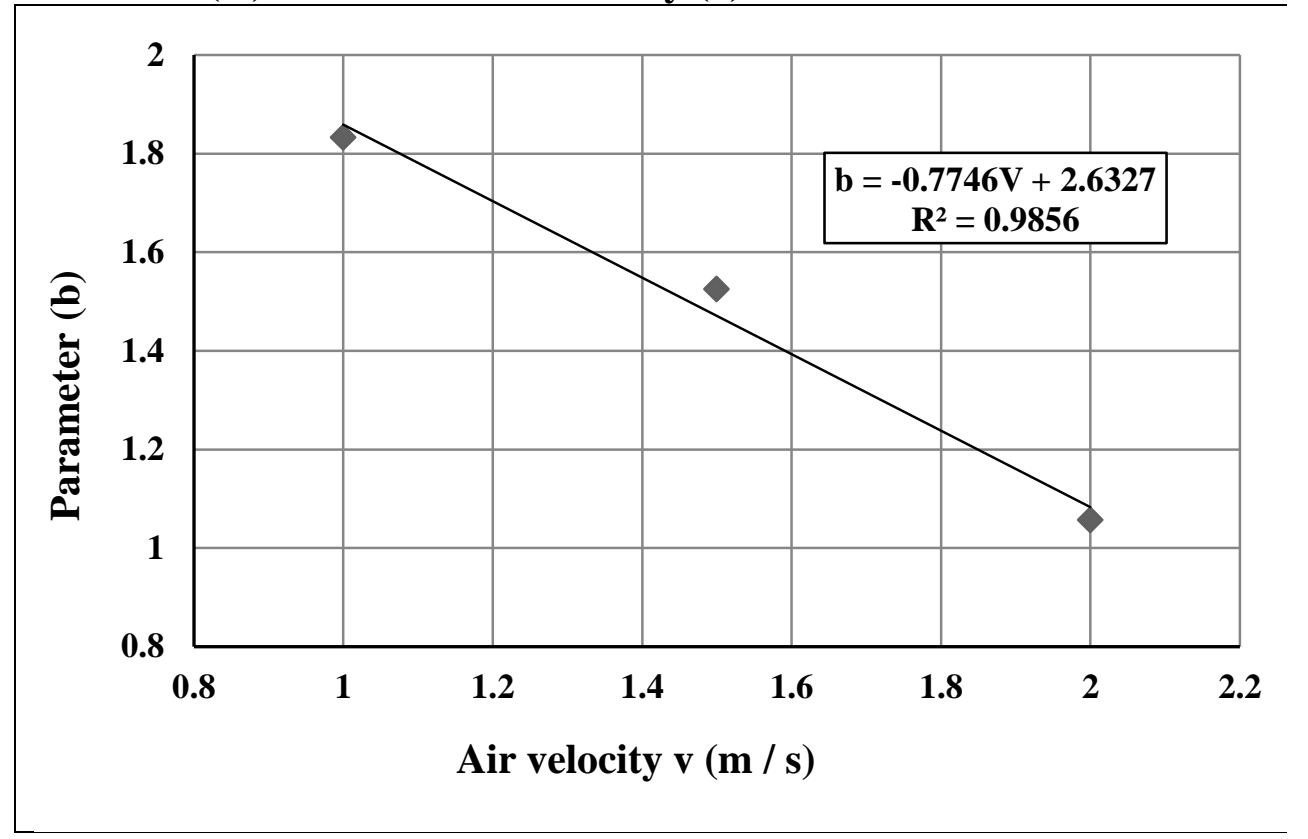

Fig. (4): Relation between parameter (b) and air velocity $v(\mathrm{~m} / \mathrm{s})$. 
From equation (11) and (5) the relation was as following:

$$
M R=e^{-\left(7.53 E-05 T^{-0.7746 V+2.6327}\right) t}
$$

\section{Costs analysis:}

The operating cost $(\mathrm{LE} / \mathrm{h})$ for the convection dryer and the costs of kilogram dried product for shrimp by-product by equation (7) and (8).

The costs for were calculated at the drying conditions that achieved the highest quality of the product and less drying time.

The operating cost of convection dryer was $1.3402 \mathrm{LE} / \mathrm{h}$ and the cost of kilogram dried product $5.843 \mathrm{LE} / \mathrm{kg}$ at dried air temperature of $80{ }^{\circ} \mathrm{C}$ and Air velocity $2 \mathrm{~m} / \mathrm{s}$.

\section{Chemical analysis:}

The chemical analysis of shrimp by-products based on dry basis, as shown in table (3).

Table (3): Chemical analysis of shrimp by-products.

\begin{tabular}{|l|c|}
\hline \multicolumn{1}{|c|}{ components } & Contents \\
\hline Protein (\%) & 54.4 \\
\hline Chitin (\%) & 9.3 \\
\hline Minerals (\%) & 21.2 \\
\hline Lipid (\%) & 11.9 \\
\hline Carotenoids (mg/kg) & 206 \\
\hline
\end{tabular}

\section{CONCLUSION}

The main objectives of the present work are to Study installation thermal dryer to drying shrimp by-products to studying of factors affecting in the drying was done. Study the results and agreement with some previous studies such as formula (Lewis's). Drying constant finding of this formula. Determine the quality of the product through chemical and economic analysis.

\section{So it was studied}


Installation thermal dryer to dry the shrimp by-products at different variables as air temperature $\left(50,60,70\right.$ and $\left.80^{\circ} \mathrm{C}\right)$ and velocity drying air $(1,1.5$ and $2 \mathrm{~m} / \mathrm{s})$.

\section{The important results:}

1- The shortest drying time was recorded at $150 \mathrm{~min}$ with $80^{\circ} \mathrm{C}$ drying air temperature and $2 \mathrm{~m} / \mathrm{s}$ air velocity. While, the longest drying time was recorded at $360 \mathrm{~min}$ with $50^{\circ} \mathrm{C}$ and $1 \mathrm{~m} / \mathrm{s}$ treatments.

2- One drying model (Lewis's) has been used to describe drying curve. The modified simple model was found to be the best fitted model to describe the drying curves in all the treatments tested.

$$
\mathrm{K}=7.53 \mathrm{E}-05 \mathrm{~T}^{-0.7746 \mathrm{~V}+2.6327} \mathrm{R}^{2}=0.9452
$$

3- Results illustrated the cost of a kilogram of dry shrimp remnants of $5.843 \mathrm{LE}$. At temperature of $80{ }^{\circ} \mathrm{C}$ and air velocity $2 \mathrm{~m} / \mathrm{s}$.

\section{REFERENCES}

AOAC (Association of official analytical chemists), (2005). Official Methods of Analysis, International Maryland, USA.

Awady, M. N.; I. Yehia; M. T. Ebaid and E. M. Arif (2003). Development and theory of rice cleaner for reduced impurities and losses, Misr J. Ag. Eng., 20 (4): 53 - 68.

Barratt A. and Montano R., (1986). Shrimp heads - a new source of protein, Info shrimp Marketing Digest 4(86): 21-22.

Galal, G., (2015). Some engineering factors affecting fish By- Products recycling. M.Sc. Dep. of Ag. Eng., Fac. of Agric., Azhar U., 4255.

Gafrd, (2013). General Authority for Shrimp Resources Development Egypt.

Lewis, W. K. (1921). The rate of drying of solid materials. J. of Industrial Eng., 5(13): 427-433.

Trang, S.T. and P.T. D. Phuong, (2012). Bioactive Compounds from By-Products of Shrimp Processing Industry in Vietnam. Journal of Food and Drug Analysis, Vol. 20, Suppl. 1: 194-197. 
Tayel, S. A.; T.H. Ghanem; A. A. El-Messery and M. M. Badr, (2012). Modeling A Microwave/Convection Dryer for Drying of Potato Slices. Misr J. Ag. Eng., 29 (4): 1377 - 1398.

Zhiqiang, G.; X. Wang, M. Li and X. Jiang, (2013). Mathematical Modeling on Hot Air Drying of Thin Layer Fresh Tilapia Fillets. Pol. J. Food Nutr. Sci., 2013, Vol. 63, No. 1: 25-34.

$$
\text { تجفيف طبقة رقيقة من مخلقات الجمبري العربى }
$$

ينتج من تجفيف الجمبري كميات كبيرة من المخلفات التي ليس لها قيمة اقتصادية وتؤثر على اليق

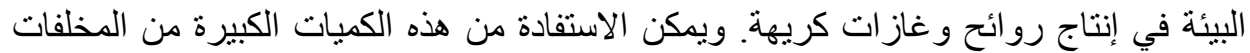
كأحد مكونات البروتين الحيو اني في علائق الدو اجن و الأسماك عن طريق التهن التجفيف و الطحن.

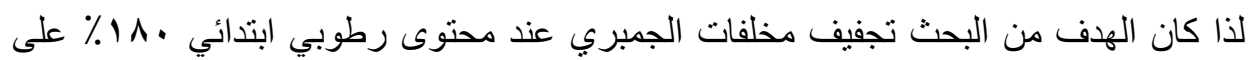

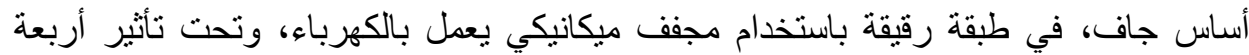

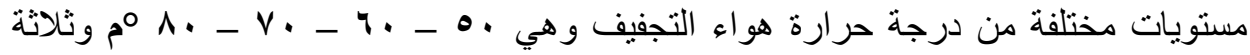

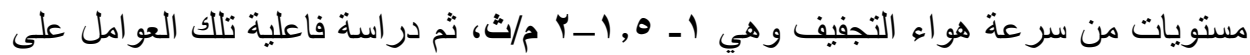

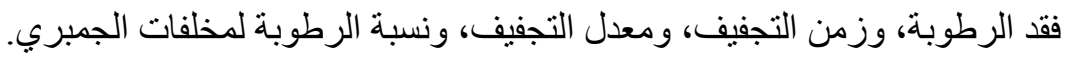
وقد تم اختبار نموذج لوصف عملية تجفيف مخلفات الجمبري في طبقة رقيقة شملت معادلة "Lewis"

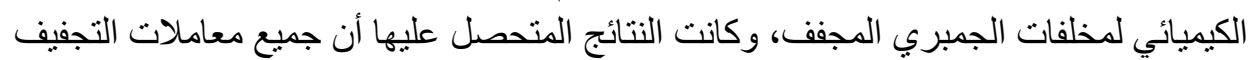

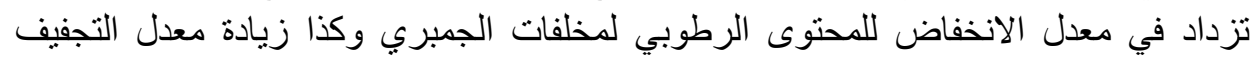
لمخلفات الجمبري بزيادة كل من درجة حر ارة وسر عة لالخة هو اء التجفيف.

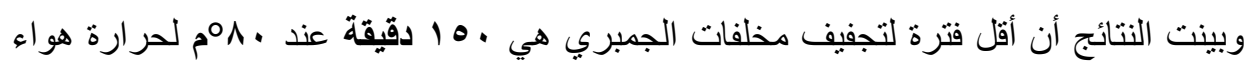

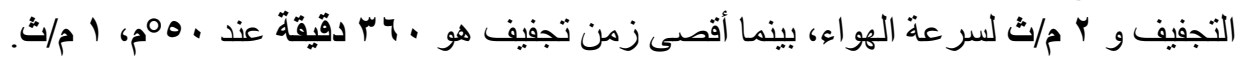

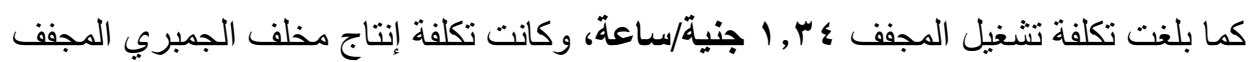

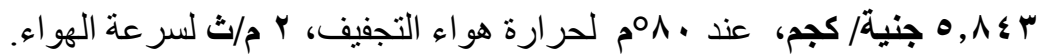

" أستاذ مساعد الهندسة الزراعية، كلية الهندسة الزراعية بالقاهرة، جامعة الأزهر. 